hexosediphosphate and creatine and a little of the specific enzyme which enables the phosphate transfer from adenylpyrophosphate to creatine, hexosediphosphate will now be decomposed into pyruvic acid as rapidly as in the presence of glucose.

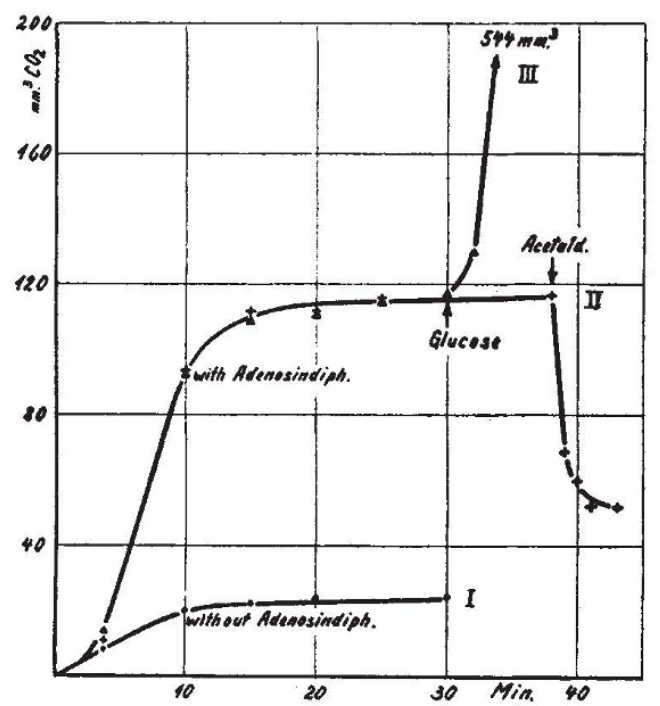

MANOMFTRIC DETERMINATION OF REDUCTION OF COZYMASE BY TRIOSEPHOSPHORIC ACID IN PRESENCE OF B-PROTFIN. CARBON DIOXIDE LIBHRATION HROM SODIUM BICARBONATE BY $\mathbf{H}+$ OF REDUCED COZYMASE AND $\mathrm{H}+$ OF PHOSPHOGLYCERIC ACID.

The specific relation between the oxidationreduction and the uptake of inorganic phosphate, which has also impressed other investigators, can be traced to a coupling of the reduction of cozymase and the phosphorylation of adenylic acid or adenosindiphosphate to adenosintriphosphate. When we omit acetaldehyde from our system and employ triosephosphate and cozymase in equiva. lent amounts, only a very slow reaction takes place ; but this reaction is accelerated enormously as soon as either a larger quantity of adenosindiphosphate or an excess of glucose with a trace of an adenylic compound is added. In the accompanying diagram the course of this conversion is demonstrated.

The measurements were made with manometric technique. The second curve is with a large amount of adenosindiphosphate. The steep upward branch of the curve shows the effect of adding glucose as indicated. This interacts with the adenosintriphosphate formed by phosphate transfer to adenosindiphosphate. The curve sloping downward shows the effect of adding acetaldehyde, by which the reduced cozymase is reoxidized. In addition to this manometric method, the hydrogenation of cozymase can be measured spectrographically. As discovered by O. Warburg, the reduced cozymase has a broad absorption band at $340 \mathrm{~m} \mu$, which is lacking in the oxidized form. From the breadth of the band the amount of reduced cozymase can be calculated. Thus, by different methods one arrives at the equations in scheme 7.

\section{J. 1 triosephosphate $+1 \mathrm{Cz}+1$ adenosindiphosphate $+\mathrm{H}_{3} \mathrm{PO}_{4}$ $=1$ phosphoglyceric acid $+1 \mathrm{CzH}_{2}+1$ adenosintriphosphate K. 1 adenosintriphosphate +1 glucose \\ $=1$ adenosindiphosphate +1 hexosemonophosphate \\ $L .=J+K, 1$ triosephosphate $+1 \mathrm{Cz}+1$ Glucose $+1 \mathrm{H}_{\mathbf{8}} \mathbf{P O}$ $=1$ phosphoglyceric acid $+1 \mathrm{CzH}_{\mathbf{2}}+1$ hexosemono- phosphate}

(7)

Always we obtain an equivalence between esterified phosphate, reduction of cozymase, and form. ation of phosphoglyceric acid. The profound cause for this coupling between the adenylic system and the reduction of cozymase (equation $G$ ) remains to be explained.

\title{
Basin Cultivation in the United States
}

\section{By Lois Olson, Soil Conservation Service, United States Department of Agriculture}

IN an article entitled "Soil Conservation in ITropical Africa" (NATURE, 141, 268-270; Feb. 12, 1938), Dr. L. Dudley Stamp described a basin type of cultivation that is in practice in Northern Nigeria. In conclusion he states, "If America could invent a plough which will imitate the Nigerian system by replacing the long furrow by a series of isolated elongated basins, one at least of her major problems in the dry lands of the Middle West might be solved". Actually, the principle of basin cultivation described by Dr.
Dudley Stamp has been the subject of experimentation in the United States for the last ten years, and to-day several basin cultivators are on the market and in use by farmers in various parts of the country.

So early as 1927, Mr. C. T. Peacock, a Colorado ranch owner, developed a basin lister* which proved satisfactory on his land. The damming attachment consisted of a drag which followed the cutting blade. At intervals the drag was lifted,

- A double mould board plough. 


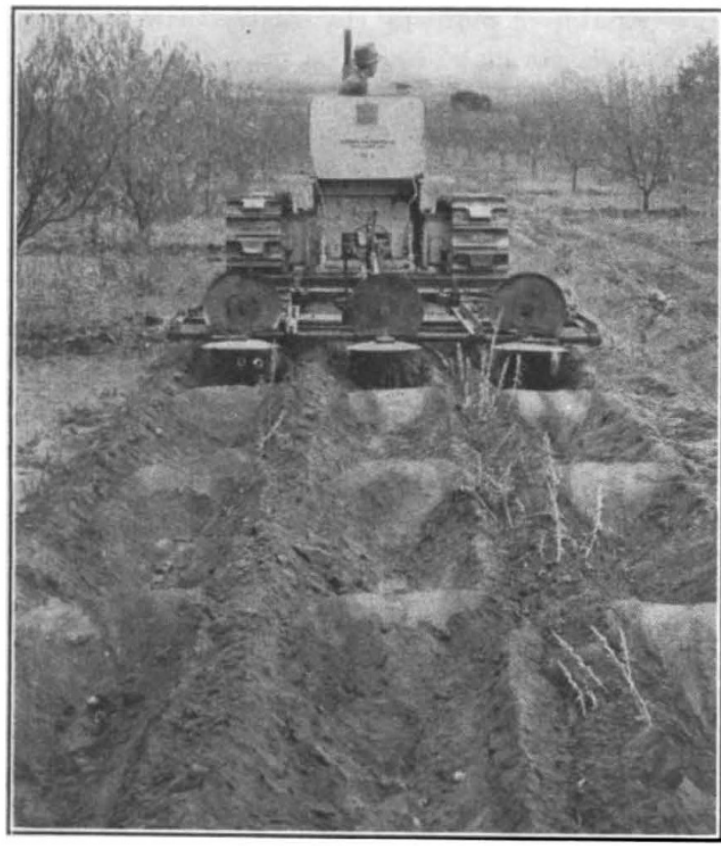

Fig. 1.

The Basin LISTER IN OPERATION IN A CaLIfornia ORCHARD.

leaving dams across the furrows. A patent was obtained in 1931. In the spring of this same year, Mr. R. H. Davis began work on a hole-digging cultivator at Hays, Kansas, and by the autumn of the year an improved model of the implement was sent to the Soil Erosion Experiment Station, Pullman, Washington, for testing. Although the machines were operated on entirely different principles, they served much the same purpose in the semi-arid sections of the country. The cultivator, which dug holes of about ten-gallon capacity, was designed primarily to retain moisture and check erosion on fallow land but later proved effective in orchards, particularly in California. Because of the pockmarked appearance of the fields, it was commonly known as the 'waffle' cultivator, and during 1931 it received considerable attention in the Press. Almost simultaneously, but completely independently, a machine which accomplished the same ends was designed in Hawaii.

In 1934 experimentation was begun on another type of basin lister at Ames, Iowa, by the Bureau of Agricultural Engineering, in co-operation with the State Experiment Station. This work was performed under the direction of J. B. Davidson, C. K. Shedd and E. V. Collins. A rotary, paddle-like attachment was used for constructing the dams.

The basin lister has several advantages over the hole-digging cultivator. The furrows, being larger than the holes, retain a larger amount of water and fill with sediment less readily. Most farmers in the Great Plains area already own listers, and the damming unit may be purchased separately and attached to an ordinary lister. Plans and specifications for the construction of a home-made damming attachment are also being distributed by the Fort Hays branch of the Kansas Agricultural Station.

The use of the basin lister raises several practical problems. If it is used for corn, the water retained in the furrow may cause the soil to form a crust on the top. If so, the young shoots may not be able to break through and an imperfect stand results. After the corn has started growth, the subsequent cultivations tend to break down the ridges between the furrows, and during the last cultivation the ridges are practically destroyed. After harvesting the corn, the land is consequently left unprotected until it is again cultivated in the spring. This means that the soil has no protection during three fourths of the year. In other circumstances dams that have been left standing present obstacles to subsequent cultivation, but several simple types of 'dam busters' have already been devised.

The space occupied by the dams reduces the water-holding capacity of the furrows, the reduction being in proportion to the space occupied by the dams. The spacing of the dams would necessarily vary with the amount of rainfall and

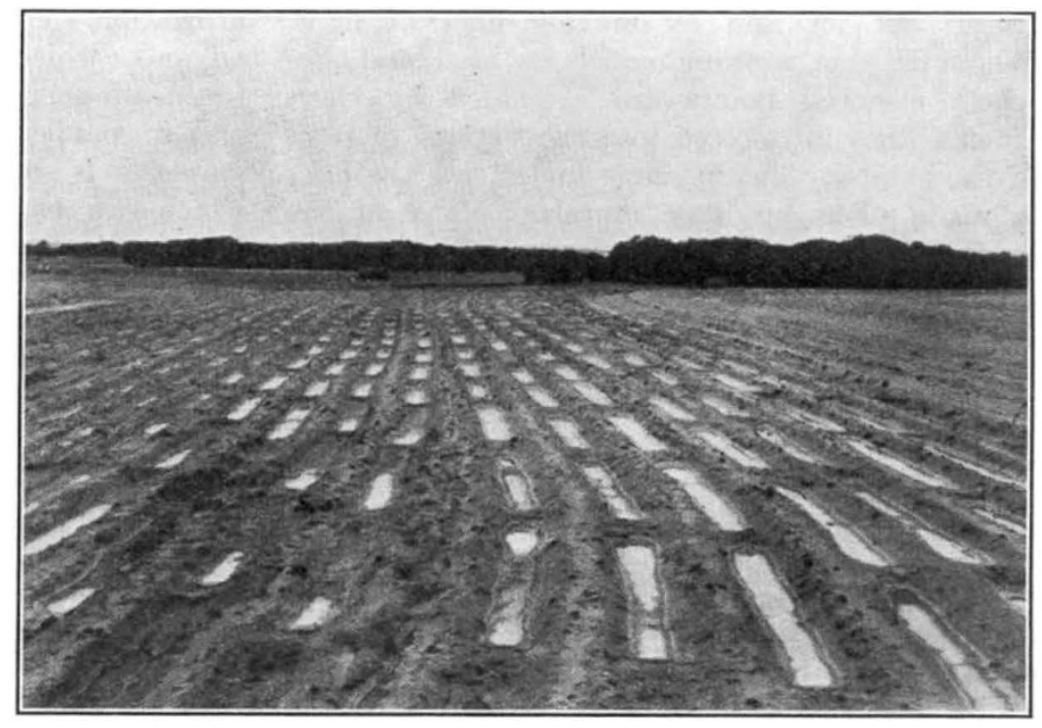

Fig. 2.

Basin listing near Hays, Kansas. 
with the position of the furrows. The closer they approach to the contours the longer the furrows may be and the greater will be their storage capacity.

As yet the basin cultivator has not been adapted to grains such as wheat, since there is no seeding device capable of planting the seeds at the different depths that would be required on a field prepared by a basin cultivator. The objections advanced, however, are not serious enough to prevent the use of the basin lister for other crops or to discourage further experimentation.

\section{Science and Industry at the Empire Exhibition, Glasgow}

$\mathrm{T}^{\mathrm{H}}$ $\mathrm{HE}$ exhibits in three of the large exhibition halls in the United Kingdom Government Pavilion at the Empire Exhibition, Glasgow, opened by H.M. the King on May 3, have been arranged by the Department of Scientific and Industrial Research in close collaboration with industry. The aim of the halls is to show the relationship now existing between science and industry, and the part which science has played in the development of British industry. The theme is illustrated by the three great national industries of coal, iron and steel, and shipbuilding-one of the exhibition halls being devoted to each of these industries. The subjects of the halls were chosen on the advice of a committee which included some of the greatest industrial leaders in the country.

In telling the story of the place which science is taking in modern industry, practically every derice of modern display has been employed to make the exhibits attractive and interesting. In this work the Department has had the help of a distinguished display expert.

Everywhere the visitor finds colour and movement. Complicated processes are simplified and traced out for him by moving lines of light. Where possible, working models are used, and elsewhere essential points are explained by short cinema films introduced into the various sections of the exhibit. The meaning underlying the halls is made plain by large murals. Many of the exhibits are demonstrated by members of the staff of the Royal Technical College, Glasgow. A novel feature of the halls is, that in the sections where a demonstrator is not provided, the various exhibits are explained in conversational tones by loudspeakers radiating the story of the section and directing attention to the various points. For this purpose a new system of sound recording employing a narrow strip of film is being used.

The first of the three industrial research halls is devoted to coal. The most prominent single exhibit in the hall is a large working model of a coal mine more than 200 square feet in area and fifteen feet in height. This has been provided for the Pavilion by the Mining Association of Great
Britain, and is probably the finest model of its kind in the world. Both underground and surface workings are illustrated in detail. The latest methods of winning coal are demonstrated and near by are exhibits illustrating the work of the Safety-in-Mines Research Board and the Miners' Welfare Committee. There are also sections dealing with the preparation of coal for the market, which show that coal as supplied to the consumer to-day has ceased to be a crude raw material and has become more and more a semi-manufactured article. Entering the hall, there is a section dealing with the origin of coal. Here there is a large representation of what a coal forest looked like some two hundred million years before the appearance of man. A short cinema film shows how the debris of such a forest was converted into coal seams. The immense varieties of British coal are illustrated by a number of pillars cut from various coal seams. In the next section of the hall the work of the National Coal Survey is illustrated, and the way in which the immense amount of knowledge now available concerning the properties of coal is being used for its better utilization. The next section deals with the great advances which have been made in the use of coal for steam generation both in large power stations and in smaller industrial plants. Here, for example, it is shown that the amount of electricity which can be obtained from a ton of coal has increased by more than 60 per cent in the last twelve years and that, in addition, improvements in electric lamps and other appliances enable electricity to be used more economically. An interesting display shows the products of combustion in super-power station practice, in good and bad industrial practice, and in domestic heating. Something of the latest researches in domestic heating which are now being carried out is also illustrated.

The other side of the hall is devoted entirely to an exhibit prepared by the British Gas Federation dealing with the carbonization of coal in gasworks, coke ovens and low-temperature carbonization plants. The whole process of the treatment of coal and also many of the by-products 